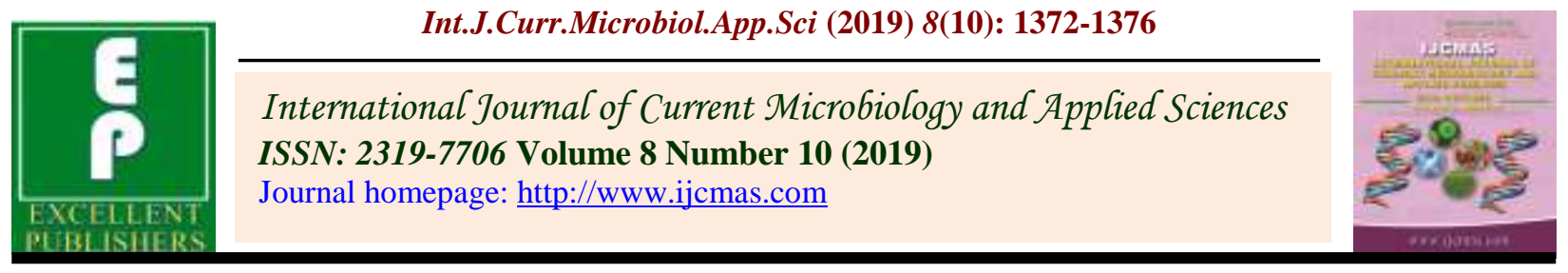

Original Research Article

https://doi.org/10.20546/ijcmas.2019.810.160

\title{
Genetic Variability in Brinjal (Solanum melongena L.) under Konkanagro Climatic Conditions
}

\author{
V. G. Magar ${ }^{1 *}$, P. C. Haldavnekar ${ }^{1}$ and P. G. Magar ${ }^{2}$ \\ ${ }^{1}$ Department of Horticulture, Dr.BSKKV, Dapoli, India \\ ${ }^{2}$ Department of Horticulture, Dr.PDKV Akola, India \\ *Corresponding author
}

\section{A B S T R A C T}

\section{Keywords}

Genetic variability, Brinjal, Konkan

Article Info

Accepted:

12 September 2019

Available Online:

10 October 2019
In this research fifty $\mathrm{F}_{4}$ progenies of brinjal were subjected to study the extent of variability present in the experimental material. Analysis of variance indicated presence of large variability for different characters under study. Most of the growth, flowering, fruit and yield characters under study were found significantly varied. The magnitude of phenotypic variance was greater than genotypic variance in all the characters under the study. The magnitude of the genotypic variance was greater than environmental variance for most of the characters except days to last harvest, days to first harvest and harvesting span. High heritability values were obtained for most of the characters studied except days to last harvest, days to first harvest, harvesting span. The highest estimates of genetic advance were recorded in fruit weight. Similarly the high values of genetic advance accompanied by higher heritability were observed for the character fruit weight. Genotypes 86 and 88-7 for earliness, 60 for maximum length of fruit, 57 for maximum girth and maximum weight of fruit, 62, 64, 72 and 88-2 for maximum harvesting span, 62 for maximum number of fruits, 62 for maximum number of fruit per plant, and 71 and 61 for yield were found promising, hence can be utilized for improvement for these traits in brinjal.

\section{Introduction}

Genetic improvement programme depends on the existence, nature and extent of genetic variation available for manipulation within the species. Assessment of available genetic variability for important economic traits to develop high yielding varieties is an important function in crop breeding. To achieve a success in breeding programme a breeder needs to know the extent of variability present in the available germplasm. Keeping in view the above mentioned objectives the present investigation was carried out to assess the genetic variability present in the experimental material. However, in Konkan region also it shows wide variation in growth habit as well as fruit characters. Thus, it indicates a high 
degree of variation with respect to vegetative growth, fruit size and shape, fruit yield and reaction to pest and diseases exist among the local types. Due to existence of wide genetic variation in the brinjal in the Konkan region, farmer has an opportunity to grow brinjal genotype as per the location specific consumer's preference. Thus, by taking into consideration the variation in growth and fruit characters and tolerance to bacterial wilt, most of the local types have been selected from Konkan region and after screening to bacterial wilt tolerance, growth and yield performance half diallel crosses were made at the Department of Horticulture during the year 2008-2009.

\section{Materials and Methods}

The field experiment was conducted at the Educational Research Farm, Department of Horticulture, Dr. BalasahebSawant Konkan Krishi Vidyapeeth, Dapoli (M.S.) during the rabi season 2012-13. The soil of experimental plot was lateritic and acidic in reaction with $\mathrm{pH}$ ranging from 5.6 to 6.5 .

The selection of the site was considered on the basis of suitability of land for the cultivation of brinjal. The investigation consisted of $50 \mathrm{~F}_{4}$ progenies of brinjal and studied in Randomized Block Design with two replications. To record the biometric observations, sampling technique was used. The statistical analysis of the data was done by using the standard methods as described by Panse and Sukhatme (1988). The standard error (S.E.) of means was worked out and critical differences (CD) at $5 \%$ level work out whenever the results were significant.

\section{Results and Discussion}

While studying the genetic variability regarding growth, flowering, fruit characters and yield contributing characters of $F_{4}$ progenies of 50 brinjal progenies; it was observed that plant height, number of primary branches per plant, number of secondary branches per plant, number of leaves, plant spread, number of fruits per plant, yield per plant, yield per hectare, fruit length, fruit girth and fruit weight were significantly varied.

The estimates of variance due to these three components for seventeen characters are presented in Table 1.

The phenotypic, genotypic and environmental variance for various characters ranged from 0.0944 to $1649.57,0.0845$ to 1639.4 and 0.0099 to 434.27 respectively. The magnitude of phenotypic variance was greater than genotypic variance. The phenotypic variance was maximum for fruit weight per plant (1649.57) followed by number of leaves (1237.71), plant height (138.62), yield per hectare (72.76) and plant spread (60.85), while it was minimum for yield per plant (0.0944) and number of primary branches $(0.1569)$. The magnitude of genotypic variance was maximum for fruit weight (1639.4) followed by number of leaves (803.44), plant height (116.68) and yield per hectare (65.13), while minimum for yield per plant (0.0845) and number of primary branches (0.1469).

The magnitude of the genotypic variance was greater than environmental variance for the characters plant height, number of primary branches, number of secondary branches, number of leaves, plant spread, days for initiation of flowering, days for fifty percent flowering, length of fruit, girth of fruit, fruit weight, days to first harvest, number of harvest, number of fruits per plant, yield per plant and yield per hectare, indicating the greater role played by the genetic component in the expression of these characters.

Further, the characters namely days to last harvest and harvesting span had greater 
magnitude of environmental variance than the genotypic variance indicating that environmental factor has greater role to influence the days to last harvest and harvesting span.

The estimates of coefficient of variation at phenotypic level (PCV) and the genotypic level (GCV) are given in Table 2.
In general, phenotypic coefficient of variation (PCV) was greater in magnitude than the respective genotypic coefficient of variation (GCV).The lowest phenotypic coefficient of variation exhibited by character days to last harvest $(1.99 \%)$, while it was the highest for the character fruit weight $(43.29 \%)$ followed by number of fruits per plant $(29.47 \%)$, fruit length $(25.66 \%)$ and yield per ha $(21.77 \%)$.

Table.1 Estimates of phenotypic variance $\left(\delta^{2} \mathrm{p}\right)$, genotypic variance $\left(\delta^{2} \mathrm{~g}\right)$, environmental variance $\left(\delta^{2} \mathrm{e}\right)$

\begin{tabular}{|c|c|c|c|c|}
\hline $\begin{array}{l}\text { Sr. } \\
\text { No. }\end{array}$ & Character & $\delta^{2} \mathbf{p}$ & $\delta^{2} g$ & $\delta^{2} \mathrm{e}$ \\
\hline 1. & Plant height $(\mathrm{cm})$ & 138.67 & 116.68 & 21.94 \\
\hline 2. & Number of primary branches & 0.16 & 0.15 & 0.01 \\
\hline 3. & $\begin{array}{c}\text { Number of secondary } \\
\text { branches }\end{array}$ & 0.44 & 0.28 & 0.17 \\
\hline 4. & Number of leaves & 1237.71 & 803.44 & 434.27 \\
\hline 5. & Plant spread (cm) & 60.85 & 50.13 & 10.73 \\
\hline 6. & $\begin{array}{l}\text { Days for initiation of } \\
\text { flowering }\end{array}$ & 38.42 & 24.41 & 14 \\
\hline 7. & $\begin{array}{l}\text { Days for fifty per cent } \\
\text { flowering }\end{array}$ & 17.15 & 9.05 & 8.11 \\
\hline 8. & Length of fruit $(\mathrm{cm})$ & 8.10 & 7.92 & 0.19 \\
\hline 9. & Girth of fruit $(\mathrm{cm})$ & 9.82 & 9.27 & 0.56 \\
\hline 10. & Fruit weight (g) & 1649.57 & 1639.40 & 10.16 \\
\hline 11. & Days to first harvest & 16.56 & 10.41 & 6.15 \\
\hline 12. & Days to last harvest & 5.50 & 2.41 & 3.09 \\
\hline 13. & Harvesting span(Days) & 23.75 & 11.34 & 12.41 \\
\hline 14. & No. of harvest & 0.53 & 0.30 & 0.24 \\
\hline 15. & No. of fruits/ plant & 29.21 & 19 & 10.21 \\
\hline 16. & Yield/ plant (kg) & 0.094 & 0.084 & 0.0099 \\
\hline 17. & Yield/ha (tonnes) & 72.76 & 65.13 & 7.63 \\
\hline
\end{tabular}


Table.2 Estimates of genetic parameters for various characters in brinjal

\begin{tabular}{|c|c|c|c|c|c|c|}
\hline $\begin{array}{l}\text { Sr. } \\
\text { No. }\end{array}$ & Character & $\begin{array}{r}\text { PCV } \\
(\%)\end{array}$ & $\begin{array}{l}\text { GCV } \\
(\%)\end{array}$ & $\begin{array}{c}\mathbf{H}^{2} \mathbf{b s} \\
(\%)\end{array}$ & GA & $\begin{array}{c}\text { GAM } \\
(\%)\end{array}$ \\
\hline 1. & Plant height $(\mathrm{cm})$ & 14.09 & 12.92 & 84.17 & 20.41 & 24.43 \\
\hline 2. & Number of primary branches & 18.09 & 17.50 & 93.63 & 0.76 & 34.89 \\
\hline 3. & $\begin{array}{l}\text { Number of secondary } \\
\text { branches }\end{array}$ & 8.71 & 6.86 & 61.92 & 0.85 & 11.11 \\
\hline 4. & Number of leaves & 17.01 & 13.71 & 64.91 & 47.04 & 22.75 \\
\hline 5. & Plant spread $(\mathrm{cm})$ & 9.48 & 8.60 & 82.37 & 13.23 & 16.08 \\
\hline 6. & $\begin{array}{l}\text { Days for initiation of } \\
\text { flowering }\end{array}$ & 14.59 & 11.63 & 63.54 & 8.11 & 19.10 \\
\hline 7. & $\begin{array}{l}\text { Days for fifty percent } \\
\text { flowering }\end{array}$ & 8.12 & 5.90 & 52.75 & 4.50 & 8.83 \\
\hline 8. & Length of fruit $(\mathrm{cm})$ & 25.66 & 25.36 & 97.69 & 5.73 & 51.64 \\
\hline 9. & Girth of fruit $(\mathrm{cm})$ & 18.69 & 18.15 & 94.35 & 6.09 & 36.32 \\
\hline 10. & Fruit weight (g) & 43.29 & 43.16 & 99.38 & 83.15 & 88.63 \\
\hline 11. & Days to first harvest & 6.61 & 5.24 & 62.84 & 5.27 & 8.56 \\
\hline 12. & Days to last harvest & 1.99 & 1.37 & 43.85 & 2.12 & 1.80 \\
\hline 13. & Harvesting span (Days) & 8.63 & 5.96 & 47.74 & 4.79 & 8.49 \\
\hline 14. & No. of harvest & 7.80 & 5.83 & 55.70 & 0.84 & 8.96 \\
\hline 15. & No. of fruits/ plant & 29.47 & 23.77 & 65.03 & 7.24 & 39.48 \\
\hline 16. & Yield/ plant(kg) & 21.77 & 20.60 & 89.50 & 0.57 & 40.15 \\
\hline 17. & Yield/ha (tonnes) & 21.77 & 20.60 & 89.51 & 15.73 & 40.15 \\
\hline
\end{tabular}

The minimum genotypic coefficient of variation was exhibited by the days to last harvest $(1.32 \%)$ and days to first harvest (5.24 $\%$ ), while it was highest in the fruit weight (43.16\%) followed by length of fruit $(25.36$ $\%)$, number of fruits per plant $(23.77 \%)$ and yield per plant $(20.60 \%)$. The lower genotypic coefficient of variation was observed for days to last picking.

High heritability values were obtained for most of the characters studied except days to last harvest, harvesting span and indicated that in the expression of these characters genetic components played an important role. Heritability in broad sense ranged from 43.65 $\%$ to $99.38 \%$. Highest heritability value was recorded for the fruit weight $(99.38 \%)$, followed by length of fruit (97.69\%), girth of fruit $(94.35 \%)$, number of primary branches $(93.63 \%)$, yield per plant $(89.51 \%)$ and yield per ha $(89.51 \%)$, height $(84.17 \%)$, plant spread $(82.37 \%)$.

The moderate value for heritability estimates was noticed in days to last harvest (43.85\%), harvesting span $(47.74 \%)$ and days for fifty percent flowering $(52.75 \%)$.

The highest estimates of genetic advance were recorded in fruit weight (83.15) followed by number of leaves (47.04), plant height (20.41), yield per hectare (15.73) indicating the possibility of improvement in these characters 
by selection, while lowest estimates of genetic advance were recorded in yield per plant $(0.57)$ and number of primary branches $(0.76)$.

The high heritability along with genetic advance is more useful for selection than heritability alone. The high values of genetic advance accompanied by higher heritability were observed for the character fruit weight, plant height and yield per hectare.

The genetic advance as percentage of mean ranged from 1.80 to 88.62 percent. The highest value was recorded for fruit weight $(88.62 \%)$ followed by fruit length $(51.63 \%)$ yield per plant $(40.15 \%)$ while lowest value was observed in days to last harvest $(1.80 \%)$.

\section{References}

Baswana, K. S., Bhatia M. K. and Dharmaveer D. (2002). Genetic variability and heritability studies in rainy season brinjal (Solanum melongena L.). Haryana $J$. Hort.Sci.31(1/2): 143-145.

Behera, T. K., Singh N. and Kalda T. S. (1999). Genetic variability studies in eggplant in relation to shoot and fruit borer infestation. The Orissa Journal of Horticulture.27(1): 1-3.

Kumar, S., Sharma, J. P. and Chopra Sandeep (2011). Studies on Variability, Heritability and Genetic Advance for Morphological and Yield Traits in Brinjal (Solanum melongena L.). Mysore J. Agric, Sci. 45 (1): 63-66.

Mahaveer, P., Mehta Nandan, Dikshit, S.N., Nichal, S.S. (2004). Genetic variability, genetic advance and heritability in brinjal (Solanum melongena L.). The Orissa Journal of Horticulture. 32(2): 26-29.
Mishra, S.V., Warade, S.D. and Nayakwadi, N.B. (2008). Genetic variability and heritability studies in brinjal. Journal of Maharashtra Agric Univ. 33 (2): 267-268.

Mohanty, B.K. (2001). Genetic Variability, correlation and path coefficient studies in brinjal. Ann.agric.Res. 22(1):59-63.

Mohanty, B.K., and Prusti, A.M. (2002). Variability and selection parameters for economic characters in brinjal. The Orissa J. Hort.30(1): 1-4.

Naliyadhara, M.V., Golani, I. J., Mehta, D.R and Purohit, V. L. (2007). Genetic variability, correlation coefficient and path analysis in brinjal. The Orissa Journal of Horticulture. 35(2): 92-96.

Negi, A.C., Baswana, K. S., Singh, Sanwal, S. K. and Batra, B. R. (2000). Studies on genetic variability and heritability in brinjal. (Solanum melongena L.) under high temperature condition. Haryana J. Hort. Sci.29(3/4): 205-206.

Prabhu, M. and Natarajan S. (2008). Variability and Heritability in segregating generation of eggplant (Solanum melongenaL.). Madras Agric. J.95(1-6): 187-190.

Prasad, M., Mehta N., Dikshit, S. N. and Nichal, S. S. (2004). Genetic variability, genetic advance and heritability in brinjal. The Orissa J. Hort. 32(2): 26-29.

Sharma and Swaroop K. (2000). Genetic variability and character association in brinjal (Solanum melongenaL.). Indian J. Hort. 57(1):59-56.

Singh, O. and Kumar, J. (2005). Variability, heritability and genetic advance in brinjal. Indian J. Hort.62(3): 265-267.

Tidke, D., Dod, V. N. and Yadgirwar, B. M. (2006). Genetic variability and correlation studies in eggplant. Crop. Prot. Prod. 2(2):79-80.

\section{How to cite this article:}

Magar, V. G., P. C. Haldavnekar and Magar, P. G. 2019. Genetic Variability in Brinjal (Solanum melongena L.) under Konkanagro Climatic Conditions. Int.J.Curr.Microbiol.App.Sci. 8(10): 1372-1376. doi: https://doi.org/10.20546/ijcmas.2019.810.160 